\title{
Evaluation of plum cultivars grafted on 'Wangenheim Prune' rootstock in the northeast of Poland
}

\author{
Bogumil Markuszewski*, Jan Kopytowski
}

\author{
Department of Horticulture \\ University of Warmia and Mazury in Olsztyn \\ Prawocheńskiego 21, 10-957 Olsztyn, Poland
}

\begin{abstract}
The study was conducted in the years 2007-2012 at the Didactic and Experimental Station of the University of Warmia and Mazury in Olsztyn in order to select plum cultivars suitable for growing on 'Wangenheim Prune' rootstock in northeastern Poland. The study encompassed the following plum cultivars: 'Herman', 'Čačanska Rana', 'Dąbrowicka Prune', 'Promis', 'Elena' 'Tolar', 'Bluefre', 'Top', 'President' and 'Valor'. The measurements taken included: trunk growth, yield, weight of one fruit, size of fruit, the content of dry matter, ascorbic acid, total and simple sugars and organic acids. We found that the 'Valor' and 'Herman' trees grew the best and 'Top' grew the most poorly. The highest yields were gathered from the 'President', 'Valor' and 'Bluefre' trees. 'Bluefre' had the largest fruit size. The highest content of dry matter was found in the fruit of 'Tolar', 'Valor' and 'Promis'. The fruit of 'Bluefre', 'Tolar' and 'Top' had the highest concentration of ascorbic acid. The highest content of total sugars and simple sugars was detected in the fruit of 'Tolar', while the highest concentrations of organic acids were found in the fruit of 'Čačanska Rana', 'Dąbrowicka Prune' and 'Top'. 'Promis', 'Herman', 'Valor', 'Top' and 'Tolar' had the highest sugar/acid indexes.
\end{abstract}

Key words: fruit morphology, growth, productivity index, quality and chemical composition, yielding

\section{INTRODUCTION}

The production of plums in Europe has totalled approximately 2.7 million tons for many years and the largest producers of this fruit are Serbia, Romania and Spain. The plum is one of the most important fruit tree species in Poland, with an annual fruit harvest in Poland at the level of 100,000 tons for many years. It ranks third in the fruit harvest ranking (3.8\%), after apple and sour cherry. The annual fruit harvest in northeastern Poland has been stable at 2,500 tons for many years. These are the lowest yields in this part of the country (FAOSTAT 2011, CSO 2012). The main reason for this is the spring frosts during the flowering of plum trees (Grabowski and Zielenkiewicz 2000).

The cultivation of new plum cultivars improves the production characteristics of plums, which increases productivity and makes the fruit more attractive in size and nutritive composition. 'Amers', 'Bluefre', 'Čačanska Rodna' and 'President' are the most prolific plum cultivars (Blažek et al. 2004, Rozpara and Grzyb 2007). Most of the late plum cultivars have a higher content of dry matter and sugars than the early cultivars. The resistance of novel cultivars to the plum pox virus (sharka) is also important, as these cultivars are more tolerant

\footnotetext{
*Corresponding author.

Tel.: +48 8952451 37; fax: +48 8952333 32;

e-mail: bogumil.markuszewski@uwm.edu.pl (B. Markuszewski).
} 
of this disease. These cultivars include the Polish clones of 'Common Prune': 'Tolar', 'Promis' and 'Nectavit' (Walkowiak-Tomczak 2009, Miloševic and Miloševic 2011b).

The selection of rootstock suitable for the cultivar and the soil and climatic conditions also has a significant effect on plum production. 'Wangenheim Prune' seedling rootstock (on which the grafted trees enter the fruiting period earlier and yield abundantly) is recommended for intensive plum orchards. Moreover, the fruit mature earlier than on trees grafted on Myrobalan seedlings (Blažek et al. 2004, Rozpara and Grzyb 2007).

Knowledge of plum resistance to the climatic conditions and the fruit maturation time (which allows the selection of cultivars to match specific soil and climatic conditions) is crucial in plum production (Sosna 2004, Blažek and Pištěková 2012). Northeastern Poland is characterised by unfavourable climatic factors and worse soil conditions than the rest of the country, making plum growing in this region even more difficult (Grabowski and Zielenkiewicz 2000).

The aim of this study was the selection of plum cultivars suitable for growing on 'Wangenheim Prune' rootstock in the northeast of Poland.

\section{MATERIAL AND METHODS}

The experiment was conducted in the years 20072012 at the Didactic and Experimental Station of the University of Warmia and Mazury in Olsztyn in northeastern Poland $\left(54^{\circ} 46^{\prime} \mathrm{E} ; 20^{\circ} 29^{\prime} \mathrm{N}\right)$. The study covered 10 plum cultivars: early-ripening 'Herman' and 'Čačanska Rana', medium-ripening 'Dąbrowicka Prune' and late-ripening 'Promis', 'Elena' 'Tolar', 'Bluefre', 'Top', 'President' and 'Valor'. The young trees on 'Wangenheim Prune' seedlings were planted in spring 2005 at a distance of $4 \times 2 \mathrm{~m}$ and cultivated in a half-natural form. The experiment was planned in a randomised complete block design in three replications with four trees per plot. The experiment was established on arable soil of average-to-lower quality and was not irrigated. Agricultural practices and chemical protection were carried out according to the recommendations for commercial orchards.

The experiment studied the trunk growth, yield, weight of one fruit, size of fruit and chemical composition. Tree trunk measurements were used as the basis of calculating the value of trunk cross-sectional area (TCSA), which was assumed as a feature representing tree vigour. The yield of fruit harvested from the plot was converted into yield in $\mathrm{kg}$ per tree. The productivity index of the trees was calculated and expressed in $\mathrm{kg} \mathrm{cm}^{-2}$ on the basis of the TCSA value in autumn 2012 and total yield. The fruit size and mean fruit weight were measured based on a mixed sample consisting of 50 fruits. A chemical analysis of the fruit was performed on a 10-fruit sample of each cultivar using three replicates collected after the fruit harvest. Laboratory analyses concerned the content of the following components: ascorbic acid using the Tillman method, modified by Pijanowski (PN90/A-75101/11), total and simple sugars using the Luff-Schoorl method (PN-90/A-75101/07), organic acids according to Petersburski, converted to malic acid (PN-90/A-75/101/04), and dry matter, using a drying method at $105^{\circ} \mathrm{C}$ until a solid mass was obtained.

The results were statistically analysed using analysis of variance according to the arrangement of the experiment. The differences between means were assessed by applying the Tukey test, at a significance level of $1 \%$ for chemical analyses concerning the content of organic compounds and 5\% for other features.

\section{RESULTS AND DISCUSSION}

The trees of the studied plum cultivars grew poorly, which shows the dwarfing effect of 'Wangenheim Prune' generative seedling rootstock on growth (Sosna 2002, Rozpara and Grzyb 2007, Blažek and Pištěková 2012). Most plum cultivars were characterised by reduced tree growth after they entered the full fruiting period (Tab. 1). However, the highest tree stem increment during the experiment was in 2012. 'Valor' and 'Herman' grew the best of the tested cultivars, which was also confirmed by the research carried out by Blažek et al. (2004). Rozpara and Grzyb (1998) and Faber et al. (2002) hold a different opinion, claiming that 'Valor' grafted on 'Wangenheim Prune' seedling rootstock grows more poorly. Although according to Čmelik et al. (2007), 'Top' has plums of medium vigour; when using 'Wangenheim Prune' seedling rootstock in the experiment it was the cultivar with the poorest vigour, but it had a favourable productivity index (Tab. 1).

The yielding of the studied plum cultivars in the experiment was poor and varied, despite using the 'Wangenheim Prune' seedling rootstock (Tab. 2). This could have been caused by a spring frost that occurred in the plum flowering phase in the years 2008-2011. A large decrease in temperature in this time period was recorded in 2010 (up to $-3.0^{\circ} \mathrm{C}$ ) 
Table 1. Growth of 10 plum cultivars in the years 2007-2012 (trees planted in the spring of 2005)

\begin{tabular}{|c|c|c|c|c|c|c|}
\hline \multirow{3}{*}{ Cultivar } & \multicolumn{5}{|c|}{ Trunk cross-sectional area (TCSA), $\mathrm{cm}^{2}$} & \multirow{3}{*}{$\begin{array}{l}\text { Productivity } \\
\text { index, } \mathrm{kg} \mathrm{cm}^{-2} \\
2008-2012\end{array}$} \\
\hline & \multirow{2}{*}{$\begin{array}{c}\text { Autumn } \\
2012\end{array}$} & \multicolumn{4}{|c|}{ Increment } & \\
\hline & & $2007-2009$ & $2009 / 2010$ & $2010 / 2011$ & $2011 / 2012$ & \\
\hline Herman & $65.0 \mathrm{ab}$ & $14.0 \mathrm{ab}$ & $10.8 \mathrm{a}$ & $11.7 \mathrm{ab}$ & $15.5 \mathrm{ab}$ & $0.45 \mathrm{~d}$ \\
\hline Čačanska Rana & $30.0 \mathrm{~cd}$ & $6.5 \mathrm{~cd}$ & $5.8 \mathrm{abc}$ & $3.8 \mathrm{c}$ & $7.8 \mathrm{~cd}$ & $0.63 \mathrm{~cd}$ \\
\hline Dąbrowicka Prune & $28.2 \mathrm{~cd}$ & $5.1 \mathrm{~cd}$ & $5.0 \mathrm{abc}$ & $4.3 \mathrm{bc}$ & $7.9 \mathrm{~cd}$ & $1.13 \mathrm{abc}$ \\
\hline Promis & $34.9 \mathrm{~cd}$ & $6.8 \mathrm{~cd}$ & $5.5 \mathrm{abc}$ & $6.5 \mathrm{abc}$ & $8.8 \mathrm{bcd}$ & $0.87 \mathrm{bcd}$ \\
\hline Elena & $27.8 \mathrm{~cd}$ & $6.6 \mathrm{~cd}$ & $5.8 \mathrm{abc}$ & $5.5 \mathrm{bc}$ & $5.7 \mathrm{~cd}$ & $0.87 \mathrm{bcd}$ \\
\hline Tolar & $24.6 \mathrm{~cd}$ & $5.9 \mathrm{~cd}$ & $4.1 \mathrm{bc}$ & $3.5 \mathrm{c}$ & $5.7 \mathrm{~cd}$ & $0.94 \mathrm{a}-\mathrm{d}$ \\
\hline Bluefre & $47.3 \mathrm{bc}$ & $10.7 \mathrm{bc}$ & $7.0 \mathrm{abc}$ & $7.6 \mathrm{abc}$ & $11.3 \mathrm{bc}$ & $0.60 \mathrm{~cd}$ \\
\hline Top & $17.2 \mathrm{~d}$ & $3.1 \mathrm{~d}$ & $1.9 \mathrm{c}$ & $1.9 \mathrm{c}$ & $4.4 \mathrm{~d}$ & $1.21 \mathrm{ab}$ \\
\hline President & $33.5 \mathrm{~cd}$ & $7.0 \mathrm{~cd}$ & $5.8 \mathrm{abc}$ & $4.5 \mathrm{bc}$ & $7.6 \mathrm{~cd}$ & $1.46 \mathrm{a}$ \\
\hline Valor & $76.7 \mathrm{a}$ & $19.8 \mathrm{a}$ & $8.5 a b$ & $13.4 \mathrm{a}$ & $21.5 \mathrm{a}$ & $0.55 \mathrm{~d}$ \\
\hline
\end{tabular}

Means followed by the same letter in columns are not significantly different at $\mathrm{p}=0.05$, according to the Tukey test

and in 2011 (up to $-1.9^{\circ} \mathrm{C}$ ). According to Grabowski and Zielenkiewicz (2000), a spring frost during the plum flowering phase occurring in the Olsztyn area in the third ten days of April and the first ten days of May has a significant effect on the plum yielding level. The factor that impacted the low yielding of fruits in the presented experiment could have been the alternating fruiting of some plum cultivars. The 'Herman', 'Elena', 'Bluefre' and 'Top' cultivars showed a tendency for alternating fruiting, which was confirmed by other studies that evaluated the yields of these cultivars (Faber et al. 2002, Blažek and Pištěková 2012). The late entry of the investigated plum cultivars into the fruiting period also exerted an impact on the low yielding. In the experiment, 'Herman' and 'Čačanska Rana' (whose first fruits were harvested in the fifth year after planting) were the last to begin fruiting
(Tab. 2). The late entry of 'Herman' and 'Čačanska Rana' into the fruiting period was also recorded by Blažek et al. (2004) and Fajt and Usenik (2010). A similar relationship for 'Herman' using Myrobalan rootstock was observed by Sosna (2004). Other cultivars of plum trees in the experiment entered the fruiting period in the third year after planting. In the first two years of plum evaluation, 'Dąbrowicka Prune' was the most productive cultivar. 'President', 'Valor' and 'Bluefre' (36.4, $35.3,26.9 \mathrm{~kg}$ tree $^{-1}$, respectively) had the highest yield total from the years 2008-2012, while the lowest were 'Čačanska Rana', 'Top', 'Tolar' and 'Elena' (14.0, 21.2, 21.3, $22.9 \mathrm{~kg} \mathrm{tree}^{-1}$, respectively). The high productivity of 'President' was proven in research by Rozpara and Grzyb (2007) and Vávra (2012). The low productivity of 'Čačanska Rana' was reported by Sosna (2002) and Blažek and

Table 2. Cropping of 10 plum cultivars until the eighth year after planting

\begin{tabular}{lccccc}
\hline \multirow{2}{*}{ Cultivar } & \multicolumn{3}{c}{${\text { Yield, kg tre } \mathrm{e}^{-1}}^{2}$} & $\begin{array}{c}\text { Total yield } \\
\mathrm{kg}_{\text {tre }}^{-1} \\
2008-2012\end{array}$ \\
\cline { 2 - 5 } & $2008-2009$ & 2010 & 2011 & 2012 & $25.3 \mathrm{c}$ \\
Herman & 0.0 & $9.7 \mathrm{a}$ & $1.0 \mathrm{e}$ & $14.6 \mathrm{bc}$ & $14.0 \mathrm{~d}$ \\
Čačanska Rana & 0.0 & $1.5 \mathrm{c}$ & $2.3 \mathrm{de}$ & $10.2 \mathrm{c}$ & $25.8 \mathrm{bc}$ \\
Dąbrowicka Prune & 4.9 & $4.4 \mathrm{bc}$ & $7.0 \mathrm{bcd}$ & $9.2 \mathrm{c}$ & $25.2 \mathrm{c}$ \\
Promis & 1.1 & $0.9 \mathrm{c}$ & $10.9 \mathrm{~b}$ & $12.4 \mathrm{bc}$ & $22.9 \mathrm{~cd}$ \\
Elena & 1.4 & $3.3 \mathrm{c}$ & $0.4 \mathrm{e}$ & $17.9 \mathrm{ab}$ & $21.3 \mathrm{~cd}$ \\
Tolar & 0.8 & $0.4 \mathrm{c}$ & $8.6 \mathrm{bc}$ & $11.6 \mathrm{c}$ & $26.9 \mathrm{abc}$ \\
Bluefre & 1.8 & $8.8 \mathrm{ab}$ & $4.3 \mathrm{cde}$ & $12.2 \mathrm{bc}$ & $21.2 \mathrm{~cd}$ \\
Top & 3.1 & $4.3 \mathrm{c}$ & $3.6 \mathrm{de}$ & $10.2 \mathrm{c}$ & $36.4 \mathrm{a}$ \\
President & 3.5 & $1.0 \mathrm{c}$ & $17.8 \mathrm{a}$ & $14.0 \mathrm{bc}$ & $35.3 \mathrm{ab}$ \\
Valor & 1.2 & $3.0 \mathrm{c}$ & $7.8 \mathrm{bc}$ & $23.3 \mathrm{a}$ & \\
\hline
\end{tabular}

Means followed by the same letter in columns are not significantly different at $p=0.05$, according to the Tukey test 
Pištěková (2012). Research by Sosna (2004) also confirmed the high productivity of 'President' trees and the low productivity of 'Čačanska Rana' trees on Myrobalan seedling rootstock.

The studied plum cultivars were characterised by larger fruit in the period when they entered full fruiting than in the first two years of their evaluation (Tab. 3). Among the early cultivars, 'Čačanska Rana' (44.2 g) had larger fruit, which was also noted by Blažek et al. (2004). The highest weight of a single fruit from the trees of the late cultivars was obtained in 'Bluefre' $(65.1 \mathrm{~g})$. The smallest fruit was gathered from the clones of 'Common Prune' ('Tolar' and 'Promis' - 18.9 and $20.4 \mathrm{~g}$ ) and 'Top' $(23.4 \mathrm{~g})$. The results obtained in the experiment are similar to the results of Blažek et al. (2004) and Rozpara and Grzyb (2007). In the research of Miloševic and Miloševic (2011a), the 'Bluefre' fruit were smaller than the 'Čačanska Rana' fruit.
A statistical analysis of the fruit parameters, determined on the basis of fruit height, width and thickness, showed substantial differences in the studied characteristics depending on the cultivar (Tab. 4). The highest levels were in 'Bluefre', 'President' and 'Valor' and the lowest were in 'Tolar', 'Elena' and 'Promis'. The widest fruit was found in 'Tolar' and the narrowest were in 'Promis' and 'Bluefre'. The fruits of 'Elena' and 'Top' were the thickest and 'Promis' had the thinnest. Evaluation of fruit parameters confirmed the differences between the cultivars during fruit weight analysis. The shape of the fruit of the cultivars studied in the experiment was confirmed by the determination of the plum fruit shape by Hodun et al. (1998) and Fajt and Usenik (2010).

Statistical analyses of the means from the years 2010-2012 showed substantial differences in the contents of chemical components in the fruit depending on the cultivar (Tab. 5). The early

Table 3. Harvest date and mean fruit weight of 10 plum cultivars

\begin{tabular}{|c|c|c|c|c|c|c|c|}
\hline \multicolumn{2}{|l|}{ Cultivar } & \multirow{2}{*}{$\begin{array}{c}\text { Harvest date } \\
2008-2012\end{array}$} & \multicolumn{5}{|c|}{ Mean fruit weight, $g$} \\
\hline Type & Name & & 2008-2009 & 2010 & 2011 & 2012 & 2010-2012 \\
\hline \multirow{2}{*}{ Early } & Herman & $21-31.07$ & - & $29.7 \mathrm{~cd}$ & $54.6 \mathrm{bc}$ & $29.6 \mathrm{ef}$ & $37.9 \mathrm{~cd}$ \\
\hline & Čačanska Rana & $25.07-5.08$ & - & $44.6 \mathrm{~b}$ & $39.3 \mathrm{~d}$ & $48.7 \mathrm{bcd}$ & $44.2 \mathrm{c}$ \\
\hline Medium & Dąbrowicka Prune & $18-30.08$ & 28.6 & $35.1 \mathrm{c}$ & $47.7 \mathrm{c}$ & $47.7 \mathrm{~cd}$ & $43.5 \mathrm{c}$ \\
\hline \multirow{7}{*}{ Late } & Promis & $31.08-20.09$ & 18.4 & $19.4 \mathrm{e}$ & $19.2 \mathrm{ef}$ & $21.1 \mathrm{f}$ & $20.4 \mathrm{e}$ \\
\hline & Elena & $1-17.09$ & 31.1 & $24.2 \mathrm{de}$ & $25.7 \mathrm{e}$ & $35.8 \mathrm{de}$ & $32.1 \mathrm{~d}$ \\
\hline & Tolar & $1-20.09$ & 17.6 & $22.2 \mathrm{de}$ & $16.5 \mathrm{f}$ & $20.1 \mathrm{f}$ & $18.9 \mathrm{e}$ \\
\hline & Bluefre & $2-21.09$ & 56.0 & $54.6 \mathrm{a}$ & $64.3 \mathrm{a}$ & $65.5 \mathrm{a}$ & $65.1 \mathrm{a}$ \\
\hline & Top & $8-13.09$ & 19.7 & $20.9 \mathrm{e}$ & $23.4 \mathrm{e}$ & $26.0 \mathrm{ef}$ & $23.4 \mathrm{e}$ \\
\hline & President & $8-22.09$ & 47.9 & $57.3 \mathrm{a}$ & $53.8 \mathrm{bc}$ & $64.1 \mathrm{ab}$ & $60.7 \mathrm{~b}$ \\
\hline & Valor & $10-21.09$ & 43.2 & $51.7 \mathrm{ab}$ & $58.2 \mathrm{ab}$ & $55.5 \mathrm{abc}$ & $56.4 \mathrm{~b}$ \\
\hline
\end{tabular}

Means followed by the same letter in columns are not significantly different at $\mathrm{p}=0.05$, according to the Tukey test

Table 4. Size of fruit of 10 plum cultivars in the years 2010-2012

\begin{tabular}{lllllllllllll}
\hline \multirow{2}{*}{ Cultivar } & \multicolumn{4}{c}{ Height $(\mathrm{cm})$} & \multicolumn{4}{c}{ Width $(\mathrm{cm})$} & \multicolumn{4}{c}{ Thickness $(\mathrm{cm})$} \\
\cline { 2 - 13 } & 2010 & 2011 & 2012 & mean & 2010 & 2011 & 2012 & mean & 2010 & 2011 & 2012 & mean \\
\hline Herman & $3.9 \mathrm{c}$ & $5.4 \mathrm{a}$ & $4.0 \mathrm{e}$ & $4.5 \mathrm{~d}$ & $3.6 \mathrm{~b}$ & $4.2 \mathrm{~b}$ & $3.7 \mathrm{~d}$ & $3.9 \mathrm{~d}$ & $3.5 \mathrm{c}$ & $4.3 \mathrm{bc}$ & $3.5 \mathrm{c}$ & $3.8 \mathrm{~d}$ \\
Čačanska Rana & $5.0 \mathrm{a}$ & $4.9 \mathrm{~cd}$ & $5.0 \mathrm{bc}$ & $5.0 \mathrm{~b}$ & $3.7 \mathrm{~b}$ & $3.7 \mathrm{c}$ & $4.1 \mathrm{c}$ & $3.8 \mathrm{~d}$ & $3.0 \mathrm{~d}$ & $3.2 \mathrm{e}$ & $3.3 \mathrm{~cd}$ & $3.2 \mathrm{e}$ \\
Dąbrowicka Prune & $4.4 \mathrm{~b}$ & $4.7 \mathrm{~d}$ & $4.9 \mathrm{c}$ & $4.7 \mathrm{c}$ & $3.7 \mathrm{~b}$ & 4.3 & $4.3 \mathrm{a}-\mathrm{c}$ & $4.1 \mathrm{c}$ & $4.2 \mathrm{a}$ & $4.4 \mathrm{ab}$ & $4.3 \mathrm{ab}$ & $4.3 \mathrm{~b}$ \\
Promis & $3.9 \mathrm{c}$ & $3.8 \mathrm{e}$ & $4.1 \mathrm{de}$ & $4.0 \mathrm{e}$ & $2.6 \mathrm{e}$ & $3.0 \mathrm{e}$ & $2.9 \mathrm{f}$ & $2.9 \mathrm{f}$ & $3.0 \mathrm{~d}$ & $2.7 \mathrm{f}$ & $2.7 \mathrm{e}$ & $2.7 \mathrm{~g}$ \\
Elena & $3.7 \mathrm{c}$ & $3.9 \mathrm{e}$ & $4.0 \mathrm{e}$ & $4.0 \mathrm{e}$ & $3.1 \mathrm{c}$ & $3.4 \mathrm{~d}$ & $3.4 \mathrm{e}$ & $3.4 \mathrm{e}$ & $4.2 \mathrm{a}$ & $4.5 \mathrm{a}$ & $4.6 \mathrm{a}$ & $4.6 \mathrm{a}$ \\
Tolar & $4.0 \mathrm{ab}$ & $3.5 \mathrm{f}$ & $4.0 \mathrm{e}$ & $3.8 \mathrm{e}$ & $4.3 \mathrm{a}$ & $4.6 \mathrm{a}$ & $4.6 \mathrm{a}$ & $4.6 \mathrm{a}$ & $3.0 \mathrm{~d}$ & $3.3 \mathrm{e}$ & $3.2 \mathrm{~d}$ & $3.2 \mathrm{e}$ \\
Bluefre & $4.9 \mathrm{a}$ & $5.2 \mathrm{ab}$ & $5.3 \mathrm{a}$ & $5.3 \mathrm{a}$ & $2.8 \mathrm{de}$ & $2.8 \mathrm{e}$ & $2.9 \mathrm{f}$ & $2.9 \mathrm{f}$ & $2.9 \mathrm{~d}$ & $2.8 \mathrm{f}$ & $3.0 \mathrm{~d}$ & $3.0 \mathrm{f}$ \\
Top & $3.9 \mathrm{c}$ & $4.1 \mathrm{e}$ & $4.5 \mathrm{~d}$ & $4.2 \mathrm{e}$ & $3.0 \mathrm{~cd}$ & $3.1 \mathrm{e}$ & $3.5 \mathrm{de}$ & $3.2 \mathrm{e}$ & $4.2 \mathrm{a}$ & $4.3 \mathrm{bc}$ & $4.5 \mathrm{a}$ & $4.4 \mathrm{ab}$ \\
President & $5.1 \mathrm{a}$ & $5.0 \mathrm{bc}$ & $5.5 \mathrm{a}$ & $5.3 \mathrm{a}$ & $4.1 \mathrm{a}$ & $4.3 \mathrm{~b}$ & $4.4 \mathrm{ab}$ & $4.4 \mathrm{~b}$ & $3.7 \mathrm{bc}$ & $4.1 \mathrm{c}$ & $4.0 \mathrm{~b}$ & $3.9 \mathrm{c}$ \\
Valor & $5.0 \mathrm{a}$ & $5.2 \mathrm{ab}$ & $5.3 \mathrm{ab}$ & $5.3 \mathrm{a}$ & $4.1 \mathrm{a}$ & $4.4 \mathrm{~b}$ & $4.2 \mathrm{bc}$ & $4.3 \mathrm{~b}$ & $4.0 \mathrm{ab}$ & $3.7 \mathrm{~d}$ & $4.1 \mathrm{~b}$ & $3.8 \mathrm{~d}$ \\
\hline
\end{tabular}

Means followed by the same letter in columns are not significantly different at $p=0.05$, according to the Tukey test 
Table 5. The content of chemical components in the fruits of 10 plum cultivars in the years 2010-2012

\begin{tabular}{lcccccc}
\hline Cultivar & $\begin{array}{c}\text { Dry matter } \\
(\%)\end{array}$ & $\begin{array}{c}\text { Ascorbic acid } \\
\left(\mathrm{mg} 100 \mathrm{~g}^{-1}\right)\end{array}$ & $\begin{array}{c}\text { Total sugars } \\
(\%)\end{array}$ & $\begin{array}{c}\text { Simple sugars } \\
(\%)\end{array}$ & $\begin{array}{c}\text { Organic acids } \\
(\%)\end{array}$ & $\begin{array}{c}\text { Sugar/acid } \\
\text { index }\end{array}$ \\
\hline Herman & $12.19 \mathrm{c}$ & $5.69 \mathrm{bc}$ & $9.9 \mathrm{ab}$ & $4.0 \mathrm{c}$ & $1.1 \mathrm{~cd}$ & $11.5 \mathrm{ab}$ \\
Čačanska Rana & $12.07 \mathrm{c}$ & $4.90 \mathrm{~d}$ & $8.3 \mathrm{ab}$ & $4.4 \mathrm{bc}$ & $1.7 \mathrm{a}$ & $5.7 \mathrm{e}$ \\
Dąbrowicka Prune & $13.82 \mathrm{bc}$ & $5.68 \mathrm{bc}$ & $6.9 \mathrm{~b}$ & $3.7 \mathrm{c}$ & $1.7 \mathrm{a}$ & $5.2 \mathrm{e}$ \\
Promis & $16.85 \mathrm{a}$ & $5.88 \mathrm{~b}$ & $9.2 \mathrm{ab}$ & $5.5 \mathrm{ab}$ & $1.0 \mathrm{~d}$ & $11.6 \mathrm{a}$ \\
Elena & $14.27 \mathrm{~b}$ & $5.03 \mathrm{~cd}$ & $7.4 \mathrm{ab}$ & $3.8 \mathrm{c}$ & $1.2 \mathrm{c}$ & $7.0 \mathrm{cde}$ \\
Tolar & $18.51 \mathrm{a}$ & $7.22 \mathrm{a}$ & $10.4 \mathrm{a}$ & $6.7 \mathrm{a}$ & $1.5 \mathrm{~b}$ & $8.1 \mathrm{a}-\mathrm{e}$ \\
Bluefre & $14.16 \mathrm{~b}$ & $7.42 \mathrm{a}$ & $7.6 \mathrm{ab}$ & $4.2 \mathrm{bc}$ & $1.4 \mathrm{~b}$ & $7.3 \mathrm{~b}-\mathrm{e}$ \\
Top & $14.25 \mathrm{~b}$ & $7.08 \mathrm{a}$ & $9.7 \mathrm{ab}$ & $3.9 \mathrm{c}$ & $1.6 \mathrm{a}$ & $10.0 \mathrm{a}-\mathrm{d}$ \\
President & $14.70 \mathrm{~b}$ & $5.55 \mathrm{bcd}$ & $8.6 \mathrm{ab}$ & $4.4 \mathrm{bc}$ & $1.3 \mathrm{bc}$ & $6.6 \mathrm{de}$ \\
Valor & $17.19 \mathrm{a}$ & $5.97 \mathrm{~b}$ & $9.7 \mathrm{ab}$ & $4.7 \mathrm{bc}$ & $1.4 \mathrm{~b}$ & $10.9 \mathrm{abc}$ \\
\hline
\end{tabular}

Means followed by the same letter in columns are not significantly different at $p=0.01$, according to the Tukey test

plum cultivars were characterised by lower dry matter contents in the fruit and the late cultivars had higher contents, whereas the fruit of 'Tolar', 'Valor' and 'Promis' contained the most of this component (18.51, 17.19 and 16.83\%, respectively). The obtained results are similar to the results of Walkowiak-Tomczak (2009). Lipecki and Janisz (2007) confirmed a higher content of dry matter in the fruits of only a few late plum cultivars.

The fruit of the late cultivars had more ascorbic acid than the early cultivars and a significantly higher ascorbic acid content was recorded in the fruit of 'Herman'. Sosna (2010) reported insignificant differences in the vitamin $\mathrm{C}$ content in fruit between early plum cultivars grafted on Myrobalan rootstock. Among the late cultivars, the fruits of 'Tolar', 'Bluefre' and 'Top' had the highest ascorbic acid contents (7.08-7.42 $\mathrm{mg} 100 \mathrm{~g}^{-1}$ ).

The fruit of the examined plum tree cultivars had a comparable content of total sugars (7.4-10.4\%), except for 'Dąbrowicka Prune', which contained the lowest concentration of these compounds (6.9\%). The highest simple sugar contents were recorded in the fruit of the late 'Tolar' and 'Promis' cultivars $(6.7 \%, 5.5 \%)$. The content of this nutrient in the fruit of other cultivars was the lowest and did not differ significantly between the examined varieties. The highest organic acid contents were measured in the fruit of 'Dąbrowicka Prune', 'Čačanska Rana' and 'Top'. The fruit of 'Promis' and 'Herman' contained the least of this component. The results of this experiment are similar to those obtained in the literature when taking into account the maturity time of the plum cultivars (Walkowiak-Tomczak 2009, Fajt and Usenik 2010).

The values for the sugar/acid index varied from 5.2 to 11.6 (Tab. 5). The highest sugar/acid indexes were recorded in the fruit of 'Promis', 'Herman', 'Valor', 'Top' and 'Tolar' and the lowest were found in 'Dąbrowicka Prune', 'Čačanska Rana' and 'President'. According to Vangdal (1985), the taste of plums depends mainly on the concentrations and proportions of sugars and acids. Fruits with a high sugar/acid index are suitable for direct consumption as they are sweeter than fruits with lower sugar/acid indexes, which are used for processing.

\section{CONCLUSIONS}

1. 'Valor' and 'Herman' showed the strongest growth and 'Top' was the weakest.

2. The highest cumulative yield was achieved by the early 'Herman' cultivar and the late 'President', 'Valor' and 'Bluefre' cultivars.

3. The highest fruit weight and size was obtained in the late-ripening 'Bluefre' cultivar.

4. The highest fruit quality based on chemical composition was observed in the following cultivars: 'Herman', 'Promis', 'Tolar', 'Bluefre', 'Top' and 'Valor'.

5. Based on the presented study, one can conclude that the most valuable plum cultivars recommended for cultivation in northeastern Poland are 'President', 'Valor', 'Bluefre' and 'Tolar'.

\section{REFERENCES}

BlAžEK J., PIŠTĚKovÁ I., 2012. Final evaluation of nine plum cultivars grafted onto two rootstocks in a trial established in 1998 at Holovousy. Hortic. Sci. (Prague) (39)3: 108-115.

Blažek J., VÁvra R., Pištěková I., 2004. Orchard performance of new plum cultivars on two rootstocks 
in a trial at Holovousy in 1998-2003. Hort. Sci. (Prague) 31(2): 37-43.

Čmelik Z., Družič Orlič J., Duralija B., Tonjko S., Strikič F., 2007. Growth and yield of plum trees 'Felsina', 'Top' and 'Elena' grafted on 'GF 655/2'. Acta Hort. 734: 337-339.

CSO., 2012. Central Statistical Office. Statistical yearbook of agriculture. Warsaw, 207.

Faber T., Lech W., MaŁodobry M., Dziedzic E., 2002. Assessment of growth and cropping of plum trees grafted on 'Wangenheim prune' rootstock and originated from in vitro. J. Fruit Ornam. Plant Res. X: 123-129.

FaJt N., Usenik V., 2010. Plum cultivar testing in the western part of Slovenia. Acta Hort. 874: 275-279.

FAOSTAT, 2011. Food and Agriculture Organization of the United Nations. http://faostat3.fao.org.

Grabowski J., Zielenkiewicz J., 2000. The effect meteorological factors during growing seasonal on yield of plums. Sodininkystė ir Daržininkystè 19(3): 203-209.

Hodun G., Hodun M., Grzyb Z.S., 1998. The promising plum cultivars evaluated in the field collection at Skierniewice, Poland. Acta Hort. 478: 193-198.

LIPECKI J., JANISZ A., 2007. Effect of hand fruit thinning on the quality of plum fruits. Annales UMCS, Sec. EEE XVII(1): 1-8 (In Polish).

MilošEvic T., MilošEvic M., 2011a. Growth, fruit size, yield performance and micronutrient status of plum trees (Prunus domestica L.). Plant Soil Environ. 57(12): 559-564.

MilošEvic T., MilošEvic M., 2011b. Quantitative analysis of the main biological and fruit quality traits of $\mathrm{F}_{1}$ plum genotypes (Prunus domestica L.). Acta Sci. Pol. Hortorum Cultus 10(2): 95-107.

PN-90/A-75101/11, 1990. Fruit and vegetable products. Preparation of samples and testing methods. Determination of vitamin C (In Polish).

PN-90/A-75101/07, 1990. Fruit and vegetable products. Preparation of samples and testing methods. Determination of sugars and sugar-free extract (In Polish).

PN-90/A-75/101/04, 1990. Fruit and vegetable products. Preparation of samples and testing methods. Determination of the total acidity (In Polish).

Rozpara E., Grzyb Z.S., 1998. Growth and yield of some plum cultivars grafted on Wangenheim Prune seedlings. Acta Hort. 478: 91-95.

Rozpara E., Grzyb Z.S., 2007. Growth, field and fruit quality of eighteen plum cultivars grafted on two rootstocks. Acta Hort. 734: 157-161.

Sosna I., 2002. Growth and cropping of four plum cultivars on different rootstocks in south western Poland. J. Fruit Ornam. Plant Res. X: 95-103.
Sosna I., 2004. The estimation of the production value of several plum cultivars grafted on 'Myrobalan' seedlings in Wrocław area. Acta Sci. Pol. Hortorum Cultus 3(1): 47-54 (In Polish).

Sosna I., 2010. Effect of pruning time on yielding and fruit quality of several early ripening plum cultivars. Acta Sci. Pol. Hortorum Cultus 9(1): 37-44.

Vangdal E., 1985. Quality Criteria for Fruit for Fresh Consumption. Acta Agric. Scand. 35: 41-47.

VÁVRA R., 2012. Evaluation of plum cultivar productivity in commercial orchards in first growing years after planting. Acta Hort. 968: 93-98.

WaLKowiak-Tomczak D., 2009. The effect of the degree of ripening on physico-chemical properties and contents of polyphenolic compounds in selected cultivars of plum (Prunus domestica). Nauka Przyr. Techno. 3,4: 1-9 (In Polish).

\section{OCENA ODMIAN ŚLIWY SZCZEPIONEJ NA PODKLADCE 'WĘGIERKA WANGENHEIMA' W PÓŁNOCNO-WSCHODNIEJ POLSCE}

Streszczenie: Doświadczenie przeprowadzono w latach 2007-2012 w zakładzie DydaktycznoDoświadczalnym Kortowo, Uniwersytetu Warmińsko-Mazurskiego w Olsztynie. Celem badań był dobór odmian śliwy do uprawy w północnowschodniej Polsce. Materiałem badawczym było dziesięć odmian śliwy szczepionej na siewkach 'Węgierki Wangenheima'. Wśród nich były dwie odmiany wczesne: 'Herman', 'Čačanska Rana', średnio późna: 'Węgierka Dąbrowicka' oraz siedem odmian późnych: 'Promis', 'Elena' 'Tolar', 'Bluefre', 'Top', 'President', 'Valor'. W doświadczeniu badano siłę wzrostu drzew, plonowanie, masę jednego owocu, parametry owoców, zawartość suchej masy, kwas askorbinowy, cukry ogółem i proste oraz kwasy organiczne. Najsilniej rosły drzewa odmiany 'Valor' i 'Herman', a najsłabiej 'Top'. Najwyższe plony zebrano z drzew odmiany 'President', 'Valor' i 'Bluefre'. Największe owoce miały drzewa odmiany 'Bluefre'. Najwyższą zawartość suchej masy odnotowano w owocach odmiany 'Tolar', 'Valor', 'Promis', a kwasu askorbinowego u 'Bluefre, 'Tolar' i 'Top'. Odmiany 'Tolar' i 'Promis' zawierały najwięcej cukrów prostych. W owocach odmian 'Čačanska Rana', 'Węgierka Dąbrowicka' i 'Top' stwierdzono najwyższą zawartość kwasów organicznych. Owoce odmian 'Promis', 'Herman', 'Valor', 'Top' i 'Tolar' miały najwyższy wskaźnik proporcji cukrów do kwasów organicznych.

Received April 26, 2013; accepted September 19, 2013 